\title{
Temporally Underspecified Bare Clauses in Mandarin
}

\author{
Hang Cheng \\ Leiden University
}

\begin{abstract}
This study shows that the temporal interpretation of Mandarin bare clauses is fully underspecified when these clauses describe scheduled, preprogrammed events. The paper defines the key syntactic properties of such bare clauses and their context of use. On the basis of this definition, the paper proposes that these clauses are copular constructions, which in all relevant respects behave like regular copular constructions. Bare clauses contain a subject and a predicate, related by the (sometimes covert) copula shì, expressing a paired relation between them. The fact that bare clauses have a simple predicative structure underlyingly is further supported by observations from the realm of gapping and negation. Crucially, it is proposed that there is no temporal projection immediately above the verb phrase in these sentences. The underspecification of the temporal interpretation is accordingly accounted for.
\end{abstract}

\section{Keywords}

bare clause, schedule, temporal underspecification, simple predication

Studies in Chinese Linguistics, Volume 42, Number 1, 2021, 1-28 DOI: 10.2478/scl-2021-0001 (C) 2021 Hang Cheng. Studies in Chinese Linguistics is published by Sciendo on behalf of T.T. Ng Chinese Language Research Centre, Institute of Chinese Studies, The Chinese University of Hong Kong. This work is licensed under the Creative Commons Attribution-NonCommercial-NoDerivatives 4.0 International License. 


\section{Introduction}

The current study discusses the underspecification of temporal interpretation that Mandarin bare clauses display in certain contexts. "Bare clauses" are defined here as clauses "without any overt aspectual marker or particle that might contribute to the temporal interpretation of the sentences" (Sun 2014: 11). ${ }^{1}$ Underspecification of temporal interpretation is possible in discourses about plans and schedules, which furthermore center on paired relations between entities and activities. Here is an example of a bare clause and the interpretation it receives in the context specified:2

(1) Context: Speakers A and B are watching a dance gala.
A: 南希 第幾個
節目?
Nánxī
dì-jì-ge
jiémù?
Nancy sequence-which.number-CLF performance
'Which performance is Nancy in?'
B: 南希 跳 胡桃夾子。(while handing the program to speaker A)
Nánxī tiào Hútáojiāzi.
Nancy dance The.Nutcracker
lit. 'Nancy dance The Nutcracker.'

The dance gala has three ballet dances performed by three groups of dancers, at 8 pm, 9 pm, and 10 pm, respectively. Assuming Nancy dances The Nutcracker at $9 \mathrm{pm}$, then Nancy's dancing is a present event if the conversation takes place at $9 \mathrm{pm}$; it would be a past event if Example (1) is uttered at $10 \mathrm{pm}$, and a future event if Example (1) is uttered at $8 \mathrm{pm}$. The understanding of the dancing event as a present, past, or future event is not fixed but varies depending on the time of the utterance.

The exemplary context of dance performances for Example (1) was first identified by Sun (2015), where the same phenomenon was examined in bare predications found in relative clauses. As Sun shows, assuming the same context as for Example (1), the noun phrase in Example (2) can refer to a girl who is dancing, who finished dancing, or who will dance at the time that John is looking for her. That no fixed temporal order is imposed on the embedded and the matrix events

1 Other versions of the definition would allow for the occurrence of particular aspectual markers in "bare clauses". For instance, Lin's (2002) definition allows for the occurrence of the progressive marker zài and the experiential marker guo. However, as will be shown later, the underspecification of temporal interpretation is only attested in clauses that have no aspectual markers at all. Henceforth, the current study adopts the "stronger" version of the definition by Sun (2014).

2 Abbreviations and conventions: clf=classifier, cop=copula, $m=$ masculine, neg=negation, $\mathrm{pfv}=$ perfective aspect marker, $\operatorname{prog}=$ progressive aspect marker, $\mathrm{q}=$ question particle, $\mathrm{sg}=$ singular, $\mathrm{sub}=$ subordinate marker; $\mathrm{Asp} \mathrm{P}=$ aspect phrase, $\mathrm{DP}=$ determiner phrase, $\mathrm{NP}=$ noun phrase, $\mathrm{TP}=$ tense phrase, $\mathrm{VP}=$ verb phrase.

3 'lit.' indicates that the relevant verb in the English translation is given without inflection, which suggests that the temporal interpretation is unspecified or in any case not marked. 
is what Sun (2015) refers to by stating that bare relative clauses in these syntactic contexts are "temporally free".

(2)

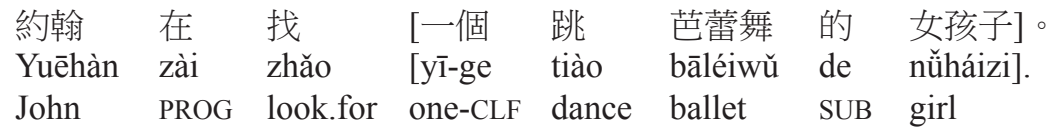

'John is looking for a girl who dances/danced/is dancing/will dance ballet.'

(Sun 2015: 63)

This flexibility in temporal interpretation, however, characterizes not only bare relative clauses (as Sun [2015] claims) but also bare main clauses, as evidenced by Example (1). This interpretation is of interest because it is only found with bare predicates, and it is highly dependent on contexts similar to the one given above. On the one hand, an aspectually marked predicate cannot be interpreted in the same way. For sentences in Example (3) to be true, the dancing event must be a present event. Likewise, for Example (4) to be true, the dancing event must be a past event. Otherwise, the sentences are false even if the same context applies as the ones that were applied to Example (1). On the other hand, if the abovementioned context is unavailable, for instance, when the sentences are uttered in isolation, the sentence B in Example (1) is either ungrammatical or can only be interpreted as a generic event. The temporally free interpretation defined above is no longer available. In contrast, the sentences in Examples (3) and (4) will still be grammatical and be interpretable.

a. 南希 在 跳 胡桃夾子。
Nánxì zài tiào Hútáojiāzi.
Nancy PROG dance The.Nutcracker
'Nancy is dancing The Nutcracker'

b. 約翰 在 找 [一個 在 跳 芭蕾舞的女孩子]。 Yuēhàn zài zhăo [ȳi-ge zài tiào bāléiwǔ de nŭháizi]. John PROG look.for one-CLF PROG dance ballet SUB girl 'John is looking for a girl who is dancing ballet.'
a. 南希 跳了 胡桃夾子。
Nánxī tiào le Hútáojiāzi.
Nancy dance PFV The.Nutcracker
'Nancy danced The Nutcracker.'
b. 約翰 在 找 [一個 跳了芭蕾舞的女孩子]。 Yuēhàn zài zhăo [ȳ̄-ge tiào le bāléiwǔ de nüháizi]. John PROG look.for one-CLF dance PFV ballet SUB girl 'John is looking for a girl who danced ballet.'

This paper is mainly concerned with two questions. First, what is the nature of the "temporally free" interpretation and why is this dependent on specific discourse contexts? Second, what accounts for the flexibility in the temporal interpretation, and why is it only associated with bare clauses? It will be proposed that the flexibility in temporal interpretation results from the lack of temporal reference 
in the clause. Bare clauses in these cases simply express a paired relation between entities and activities, which are combined without syntactic encoding of any temporal relation. Discourses about plans and schedules provide proper licensing contexts that may underscore the pairings.

The article is structured as follows. Section 2 introduces the basic properties of bare matrix clauses and the contexts in which they may occur. The proposed structural analysis is laid out in Section 3. Section 4 presents evidence corroborating the analysis. Section 5 presents the conclusions.

\section{Basic properties}

This section examines the basic properties of bare clauses that occur with the temporally free interpretation as defined above. Section 2.1 investigates the constraints on the elements occurring in bare clauses. The context and use of bare clauses are introduced in Section 2.2. The particular information structure of bare clauses is further investigated in Section 2.3. The last subsection summarizes the properties and briefly reviews the previous analyses of the sentences in question.

\subsection{Constraints}

For bare clauses to receive a temporally free interpretation in proper contexts, there are two constraints on the elements occurring in them. First, aspectual markers and temporal adverbials anchoring to the utterance time are not permitted to occur. Only adverbials disconnected from the utterance time are allowed. Second, the bare clauses under consideration must describe a scheduled or planned event.

\subsubsection{Constraints on temporal modifiers}

The distinction between the temporal interpretation of bare clauses (e.g., Examples [1] and [2]) and that of aspectually marked clauses (e.g., sentences in Examples [3] and [4]) shows that the temporally free interpretation is only available when aspectual markers are absent. Apart from aspectual markers, the occurrence of temporal adverbials that are deictically anchored to the utterance time also cancels the flexibility in temporal interpretation. For instance, with the addition of temporal adverbs such as gāngcái 'just now' and xiànzài 'now' in Example (5), the temporally free interpretation is unavailable (in fact, such a sentence is ungrammatical; see the following sentence).

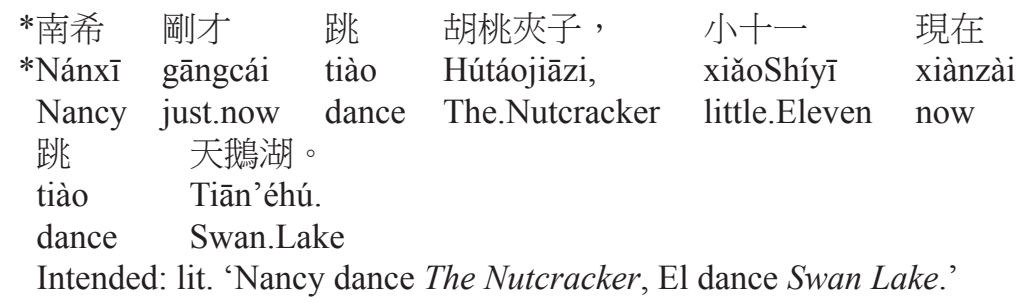

However, temporal adverbials such as calendric dates and clock expressions are generally allowed to occur (cf. Example [6]), and so are adverbials anaphorically 
anchored to another point in the discourse, as is illustrated in Example (7). The flexibility in temporal interpretation is maintained in both cases. In both Examples (6) and (7), dancing The Nutcracker can be interpreted as a past, present, or future event depending on the utterance time.

$\begin{array}{lllll}\text { a. 南希 八點 } & \text { 跳 } & \text { 胡桃夾子, } & \text { 小十一 } & \text { 十點 } \\ \text { Nánxī } & \text { bādiăn tiào } & \text { Hútáojiāzi, } & \text { xiăoShíȳī shídiăn } \\ \text { Nancy } & \text { 8.o’clock dance } & \text { The.Nutcracker } & \text { little.Eleven } & \text { 10.o’clock } \\ \text { 跳 } & \text { 天我鳥湖。 } & & & \\ \text { tiào } & \text { Tiān'éhú. } & & & \\ \text { dance } & \text { Swan.Lake } & & & \end{array}$

lit. 'Nancy dance The Nutcracker at eight o'clock, El dance Swan Lake at ten o'clock.'

$\begin{array}{llllll}\text { b. 八點 } & \text { 跳 } & \text { 胡桃夾子, } & \text { 十點 } & \text { 跳 } & \text { 天鵝湖。 } \\ \text { Bādiăn } & \text { tiào } & \text { Hútáojiāzi, } & \text { shídiăn } & \text { tiào } & \text { Tiān'éhú. } \\ \text { 8.o'clock } & \text { dance } & \text { The Nutcracker } & \text { 10.o’clock } & \text { dance } & \text { Swan Lake }\end{array}$ lit. 'The Nutcracker dance at eight o'clock, Swan Lake dance at ten o'clock.'

邁克 唱完 茉莉花 之後, 南希 跳 胡桃夾子。
Màike chàng-wán Mòlihuā zhīhòu, Nánxī tiào Hútáojiāzi.
Mike sing-finish Jasmine after Nancy dance The.Nutcracker
lit. 'After Mike finish singing Jasmine the song, Nancy dance
The Nutcracker.'

The (non)occurrence of adverbials depends on whether or not the utterance time functions as their anchoring point. For adverbials anchoring to the utterance time, such as those in Example (5), the temporal order regarding the utterance time is specified and fixed, so the clause is no longer temporally free. In contrast, when the reference of a temporal adverbial is not connected to the utterance time, the order between the time it refers to and the utterance time can only be specified after the utterance time has been specified. As a result, it varies as a function of the utterance time; in other words, it is temporally free as defined above. In addition, the ungrammaticality of sentences with temporal adverbials linked to the utterance time (such as in Example [5]) suggests that the choice of adverbials not only affects the availability of the temporally free interpretation, it also has syntactic consequences.

\subsubsection{The role of scheduled events}

Bare clauses also have a specific contextual licensing requirement. For a start, in the dance performance context of Example (1) and all the relevant examples, the dancers, the dances, as well as their scheduled time are all part of the background information about a program or some other scheduled event. Similarly, modifiers, such as manner adverbs, are also allowed in bare clauses, provided their interpretation is restricted to manners that can be planned or arranged in advance (or can be interpreted as such). For instance, Example (8) conveys that Nancy is 
supposed to dance gracefully, whereas El is supposed to dance clumsily according to the relevant choreography.

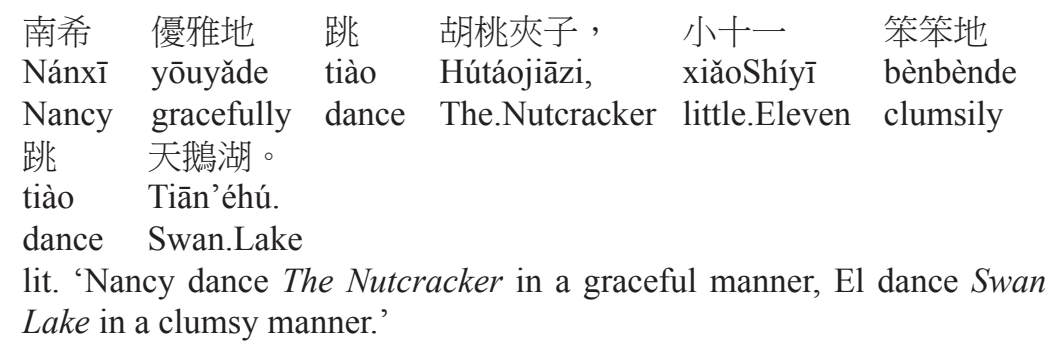

This requirement is responsible for the fact that the interpretative ambiguity of manner modifications that normally characterizes aspectually marked sentences is not available in bare clauses. For instance, the aspectually marked clause in Example (9) can express that $\mathrm{El}$ is an experienced dancer who deliberately danced Swan Lake in a clumsy way or that she is an inexperienced dancer and danced Swan Lake quite badly as a result.

$\begin{array}{lllll}\text { 小十一 } & \text { 笨笨地 } & \text { 跳 } & \text { 了 } & \text { 天鵝湖。 } \\ \text { XiăoShíyī bènbènde tiào } & \text { le } & \text { Tiān'éhú. } \\ \text { little.Eleven } & \text { clumsily dance } & \text { PFV } & \text { Swan.Lake } \\ \text { 'El danced Swan Lake in a clumsy way.' } & \end{array}$

In contrast, the two sentences in Examples (8a) and (8b) only have the meaning that the dancers deliberately dance in a graceful way and a clumsy way, respectively.

The same contextual requirement is found when we consider the (non)occurrence of the results of events. If the result of an event can be prescheduled, the resultatives are felicitous in bare clauses; otherwise, only atelic activities like Example (10a) are permitted. For instance, if the script of a play specifically requires Nancy to paint the chair red and El to paint the chair green, Example (10b) is an acceptable utterance. Conversely, if the script only mentions painting a chair without specifying the colors, Example (10b) is unavailable with the temporally free reading (in fact, the sentence is ungrammatical). ${ }^{4}$ Likewise, Example (10c) can only be used if match manipulation is under discussion; otherwise, the temporally free reading is unavailable (and the sentence is ungrammatical). ${ }^{5}$

4 It has been reported that resultatives without an aspectual marker used in isolation are grammatical for some speakers (e.g., Lin 2006). This point will be briefly discussed in Section 2.4.

5 With respect to the settledness of events and their results, Copley (2008) uses the label "futurate" for cases where a future prescheduled event is expressed in the present tense. A typical example used by Copley is the context of a match, scheduled in advance, which can be described using a futurate; whereas the result of a match, which is unknown unless match manipulation happens, cannot be described by a futurate. Mandarin shows the same: the future modal can be omitted if the future event is scheduled in advance (Sun 2014). When the future modal is omitted, the result 
(10) a. Activity

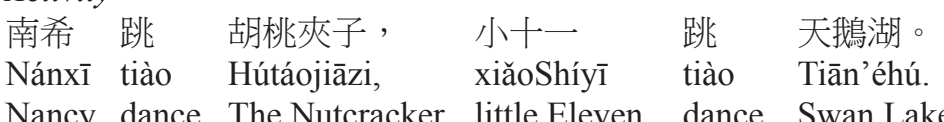
lit. 'Nancy finish dancing The Nutcracker, El finish dancing Swan Lake.'

b. Accomplishment

$\begin{array}{llllll}\text { 南希 } & \text { 塗紅 } & \text { 椅子, } & \text { 小十一 } & \text { 塗綠 } & \text { 椅子。 } \\ \text { Nánxī } & \text { tú-hóng } & \text { y̌̌zi, } & \text { xiăoShíyī } & \text { tú-lǜ } & \text { yǐzi. } \\ \text { Nancy } & \text { paint-red } & \text { chair } & \text { little.Eleven } & \text { paint-green } & \text { chair }\end{array}$
lit. 'Nancy paint the chair red, El paint the chair green.'

c. Achievement

$\begin{array}{llllll}\text { 南希 } & \text { 打贏 } & \text { 邁克, } & \text { 小十一 } & \text { 打贏 } & \text { 威爾。 } \\ \text { Nánxī } & \text { dă-yíng } & \text { Màike, } & \text { xiăoShíyi } & \text { dǎ-yíng } & \text { Wēi’ěr. } \\ \text { Nancy } & \text { play-win } & \text { Mike } & \text { little.Eleven } & \text { play-win } & \text { Will }\end{array}$

lit. 'Nancy win Mike, El win Will.'

\subsection{The context of use}

As we can see from the examples presented so far, bare clauses under investigation can be uttered as assertive statements or answers to questions. Additionally, they can pragmatically function as rebuttals or corrections, or be used as rhetorical questions or exclamations to express surprise or skepticism. The sentence in Example (11) is an example of a bare clause used to correct a previous utterance. Speaker B uses a bare clause to pragmatically imply that Nancy is not the next performer. As before, Nancy's dancing can be a past, present, or future event relative to the utterance time.

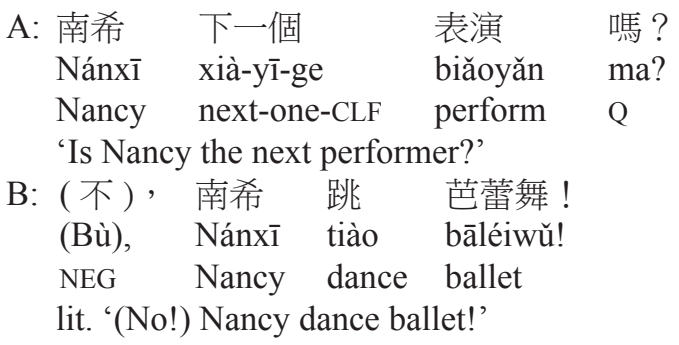

The bare clause in Example (12) initiates a conversation, expressing the speaker's skepticism or surprise about the cast of a performance. Similar to the bare clauses we have seen before, the sentence is not confined to a particular temporal interpretation. It can be uttered after the performance when the speaker is reading the review of it, before the performance if the speaker knows the cast in advance,

is a bare clause. The bare clauses under discussion here, however, are not futurate constructions, as they can describe present or past events, not necessarily future ones. 
or during the performance when the speaker sees Nancy come out from behind the curtains and start to dance.

$$
\begin{aligned}
& \text { 南希 跳 胡桃夾子? ! 真 是 個 奇怪 的 安排。 } \\
& \text { Nánxī tiào Hùtáojiāzi?! Zhēn shì ge qíguài de ànpái. } \\
& \text { Nancy dance The.Nutcracker quite COP CLF strange SUB arrangement } \\
& \text { lit. 'Nancy dance The Nutcracker?! It is quite a strange arrangement.' }
\end{aligned}
$$

In all the above examples, bare clauses with the free temporal interpretation can be said to express a paired relation between an entity and the activity that $\mathrm{s} /$ he performs. Speakers can use these sentences to question or to assert the existence of a certain pairing, defined in the context as arrangements, plans, groupings, and so forth - as the program of dancing performances illustrated in Example (1) shows.

It is worth noting that when bare clauses are used as answers to questions, they cannot function as direct answers to questions containing temporal markers. For instance, the bare clause in Example (14a) cannot serve as a direct answer to Example (13). Only the aspectually marked Example (14b) is felicitous as an answer to Example (13).

\begin{tabular}{|c|c|c|c|}
\hline b. 南希 & 在 & 跳 & 胡桃夾子。 \\
\hline Nánxī & zài & tiào & Hútáojiāzi. \\
\hline Nancy & PROG & dance & The.Nutcracker \\
\hline
\end{tabular}

$$
\begin{array}{llll}
\text { 南希 在 } & \text { 跳 } & \text { 什麼? } \\
\text { Nánxī zài } & \text { tiào } & \text { shénme? } \\
\text { Nancy PROG dance } & \text { what } \\
\text { 'What is Nancy dancing?' }
\end{array}
$$

$$
\begin{array}{ll}
\text { a. \#南希 跳 } & \text { 胡桃夾子。 } \\
\text { \#Nánxī tiào } & \text { Hútáojiāzi. } \\
\text { Nancy dance } & \text { The.Nutcracker } \\
\text { lit. 'Nancy dance } & \text { The Nutcracker.' }
\end{array}
$$

Bare clauses can be used to answer such questions as Examples (13/15a) in an indirect way only. Consider the following example. B's response in Example (15) can be a proper response to A's question 'What is Nancy dancing right now?'. However, by uttering a bare clause, B implies that although s/he does not know what Nancy is performing at present, s/he is being cooperative and offers an answer that is the best $\mathrm{s} /$ he can do under the circumstances. In other words, since the program of the performances provides a clue to the answer to A's question, indicating what Nancy is programmed to dance at different times is thus relevant and helpful. For instance, if the time of Example (15a) is specifically stated as Example (16a), A's initial question can be regarded as having been answered sufficiently (e.g., B2 in Example [16]). 
(15)
a. A: 南希 在 跳什麼?
Nánxī zài tiào shénme?
Nancy PROG dance what
'What is Nancy dancing (right now)?'
b. B: 南希 八點 跳 胡桃夾子, 十點 跳 天鵝湖。 Nánxī bādiăn tiào Hútáojiāzi, shídiăn tiào Tiān'éhú. Nancy 8.o'clock dance The.Nutcracker 10.o'clock dance Swan.Lake lit. 'Nancy dance The Nutcracker at eight o'clock, Swan Lake at ten o'clock.'

(16)
a. B1: 現在
幾
點?
Xiànzài
jĩ
diăn?
now how.much clock
'What time is it now?'
b. A：現在 八 點。
Xiànzài bā diăn.
'It is eight o'clock.'
now 8 clock
c. B2: 那麼, 南希 在 跳胡桃夾子。
Nàme, Nánxī zài tiào Hútáojiāzi.
thus Nancy PROG dance The.Nutcracker
'Thus, Nancy is dancing The Nutcracker.'

\subsection{Information structure}

As bare clauses without temporal specification only express paired relations between entities and activities, they display some specific properties in terms of information structure.

First, either member of a pair (the subject or the verbal predicate) of a bare clause can provide new information for the speaker. Take Sentence (12) as an example, repeated here as Example (17). It could be the case that the speaker knows in advance that Nancy will dance but has no idea which dance. It could also be the case that the speaker knows that The Nutcracker will be performed but does not know by whom. Additionally, it is possible that the speaker knows a list of dancers including Nancy, as well as dances to be performed, including The Nutcracker without, however, knowing the pairings between them.

$$
\begin{aligned}
& \text { 南希 跳 胡桃夾子?! 真 是 個 奇怪 的 安排。 } \\
& \text { Nánxī tiào Hútáojiāzi?! Zhēn shì ge qíguài de ānái. } \\
& \text { Nancy dance The.Nutcracker quite COP CLF strange sUB arrangement } \\
& \text { 'Nancy dance The Nutcracker?! It is quite a strange arrangement.' }
\end{aligned}
$$

Second, as the previous subsection has shown, in Mandarin, bare VPs under discussion can be used in corrections and exclamations; in addition, when they are bi- or multiclausal, they can provide lists of pairs. Admittedly, in spite of the existence of monoclause utterances such as Examples (1) and (12/17), temporally 
underspecified bare clauses are more frequently found in bi- or multiclausal structures. ${ }^{6}$ However, it is crucial here that the number of clauses is not restricted as long as all other conditions on the formation of base clauses are satisfied.

In these sentences, the syntactic form of a bare VP is apparently matched with the pragmatic or discourse functions just mentioned. We believe that this match must be conventionally established, basing ourselves on the observation that other languages express similar content in various syntactic ways (see, e.g., Akmajian 1984 and Lambrecht 1990 on the English and German equivalents of the Mandarin Examples [12/17] above). What unites all bare clauses in all occurrences in Mandarin is that they all express a subject-predicate relation in which a certain argument is paired with a certain predicate. The remainder of the paper will try to capture this property and provide a syntactic analysis that derives it.

\subsection{Interim summary and previous studies}

In sum, the preceding subsections show that in some contexts, the temporal interpretation of bare matrix clauses is free, and the specification of the temporal relation regarding the utterance time is a function of background knowledge. When interpreted in this way, they make reference to arrangements, schedules, plans, and so forth provided by the context. Bare clauses are in effect paired relations, pairing up the subject with an activity or constituent related to that activity. They can be uttered as assertions and can have the pragmatic function of rebuttals, corrections, or expressions of surprise or skepticism.

As mentioned in the Introduction section, the temporally free interpretation associated with specific contexts is not the standard interpretation that Mandarin bare clauses receive when uttered in isolation. As Sun (2014: 54-55) states in her Bare Predicate Generalisations (see also Yong 1997; Klein et al. 2000; cf. Lin 2002, Lin 2006; Smith and Erbaugh 2005 for an opposite analysis), for an eventive predicate to receive an episodic interpretation, overt aspectual marking is required. Otherwise, i.e., in the absence of aspectual marking, only the generic reading is available. For instance, when spoken out of the blue, Example (18a), a sentence with an eventive predicate lacking aspect markers, is ill-formed to describe an episodic event. It can only have the generic reading, 'The chief of police smokes/ is a smoker'. In order to express an episodic eventive reading, an aspectual marker such as the progressive marker zài in Example (18b) or the perfective marker le in Example (18c) must be added.
a. 警長
抽煙。
Jǐngzhăng chōuyān.
chief.of.police smoke

'The chief of the police smokes./The chief of the police is a smoker.'

6 Bare clauses will be compared to the so-called "special" type of copular sentences in Section 3.1. In fact, preference for using bi-/multiclausal sentence is also observed in those copular sentences (e.g., see Zhang and Tang 2010). 
$\begin{array}{lll}\text { b. 警長 } & \text { 在 } & \text { 抽煙。 } \\ \text { Jǐngzhăng } & \text { zài } & \text { chōuyān. } \\ \text { chief.of.police } & \text { PROG } & \text { smoke }\end{array}$

'The chief of the police is smoking.'

c. 警長抽了煙。

Jĩngzhăng chōu le yān.

chief.of.police smoke PFV cigarette

'The chief of the police smoked a cigarette.'

The bare clauses under discussion in this paper do not have a generic interpretation. Example (1), for instance, does not have the reading that Nancy has the habit of dancing The Nutcracker or that she does this as her profession. The statement is episodic in the sense that it is associated with a single event such as one dance in a performance, and as such, it is temporally free as defined above.

How should we account for the flexibility in the temporal interpretation of these episodic bare clauses? What structure can we propose to account for the properties associated with the freedom of temporal interpretation? Sun (2015) attributes the freedom in temporal interpretation to the flexibility of the value setting of T(ense). Specifically, she assumes that the embedded clause (recall that she restricts her discussion to relative clauses) contains a $\mathrm{T}$, and values of past, present, and future are all available for this T-head. When the value of $\mathrm{T}$ is past, the time of the event in the relative clause precedes that of the matrix clause; when it is future, the time of the event in the relative clause is later than the matrix one; and when it is present, the embedded event takes place at the same time as the matrix event. A schematic structure is given in Example (19), simplified from Sun (2015: 73) ${ }^{7}$

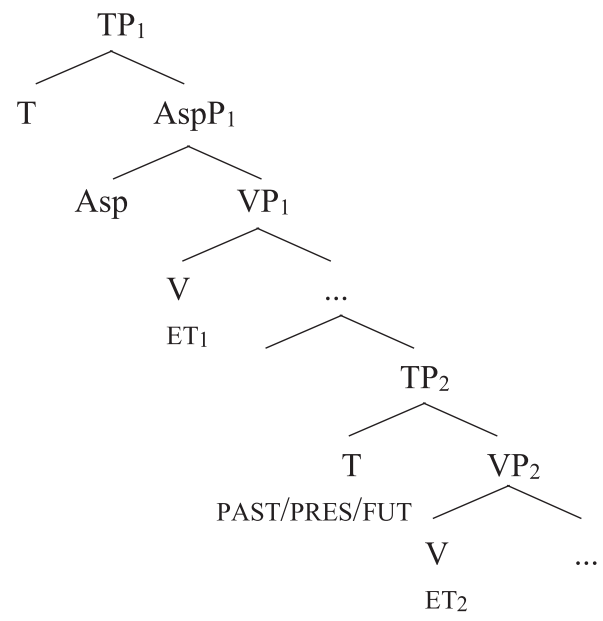

$7 \mathrm{ET}_{1}$ stands for the event time of the matrix clause; $\mathrm{ET}_{2}$ stands for the event time of the embedded clause. 
However, Sun's analysis of base relative clauses, as sketched above, cannot carry over the analysis of matrix bare clauses. For one thing, it is unclear how the flexibility of the value setting of $\mathrm{T}$ is restricted or triggered for the relative clause. In addition, if this idea is applied to a main clause, we are confronted with a situation where clauses receive an episodic reading without the presence of an aspectual marker, which contradicts the generalization of Sun (2014) and others about the interpretation of such sentences, which we discussed earlier. To overcome this problem, the next section will argue for a different structure that resembles copular sentences. Crucially, in the account that the current study argues for, the freedom of temporal interpretation will be ascribed to the lack of temporal projections in the structure right above the VP.

Before closing this section, I should make a short remark about the discrepancy in the literature regarding the obligatoriness of the aspectual markers and its theoretical consequences. This discrepancy is mainly due to the different grammatical judgments of sentences that diverging proposals are based on. The most controversial example is shown in Sentence (20). Example (20a) is grammatical for certain groups of speakers, especially speakers of Taiwan Mandarin. Research based on this type of grammaticality judgments leads to the analysis that sentences with resultative predicates are bare clauses with a default past reading (e.g., Lin 2002, Lin 2006, Lin 2010). However, Example (20a) and parallel examples are ungrammatical to other speakers, especially speakers from mainland China. For these speakers, for Example (20a) to be a felicitous episodic sentence with a past-oriented interpretation, the perfective marker $l e$ is obligatory, e.g., Example (20b).

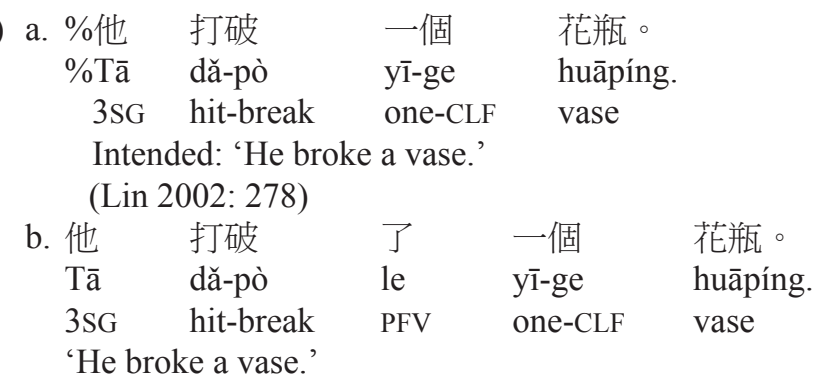

As the current study takes the grammatical judgments from Mandarin speakers from mainland China as the basis for analysis, I take the position that aspectual marking is obligatory for episodic eventive sentences and hence confine my discussion to that regional variety. This means that bare sentences uttered in isolation can never have an episodic interpretation; instead, they would either have a future or generic reading in accordance with Sun's (2014) generalization, or, in the specific contexts under discussion here, their temporal interpretation is free. In Section 2.1.2, we have looked at sentences containing a verb-result predicate, like 
the one in Example (20a). ${ }^{8}$ It has been shown that they are highly constrained to have temporal freedom in interpretation. Specifically, for instance, the result must be preestablished in the discourse.

\section{Analysis}

To account for the free temporal interpretation of bare matrix clauses in contexts addressing paired relations, the current section proposes a structure for them that is similar to that of copular sentences. Section 3.1 shows that the copula shi can occur in sentences with bare predicates without any interpretational consequences in the proper context. Section 3.2 presents the structure that I propose. The temporal interpretation is investigated in the final subsection.

\subsection{Interaction with copula shi}

As we saw in Section 2.3, the bare clauses under discussion express paired relations. Their way of expressing such relations is similar to a "special" type of copular sentences, which have attracted a lot of attention in previous studies (Chao 1968; Zhang and Tang 2010, among others). Example (21) presents two well-known examples.
a. 他
是
日本
女人。9
Tā
shì Rìběn
nürén.
3SG.M COP Japan female
lit. 'He is a Japanese woman.'
(Zhang and Tang 2010: 14)
b. 我 是雞肉,
Wǒ shì jīròu, tā shì niúròu.
1SG COP chicken.meat 3SG COP beef
'I ordered/ate chicken and he ordered/ate beef.'

These sentences are special not because of their structure but because of the semantic relations between the subjects and the predicates. For instance, Example (21a) expresses that the subject is related to a Japanese woman one way or another. The woman could be his wife, his secretary, his boss, etc. As long as the relation

8 To the best of my knowledge, Lin (2002) was the first to discuss Mandarin bare sentences. His discussion differs from the current study in two respects. First, as mentioned in Section 1, I adopt the definition that no aspectual marker can occur in bare clauses, whereas his definition allows for the occurrence of the progressive marker zài and the experiential marker guo in such sentences. Second and more crucially, the temporal underspecification is not a concern for Lin (2002) since he focuses on the properties of bare clauses when they are uttered in isolation. Besides, as mentioned in the text, Lin and this study differ in qualifying the grammaticality of eventive sentences without aspectual markers.

9 There is no gender distinction in Mandarin. The morpheme for third person singular pronoun is $t \bar{a}$. Only the characters in the writing system vary in gender and the human/nonhuman distinction. I gloss Masculine here for a better illustration of the oddness of the semantics of this sentence. 
between the man and the Japanese woman is known from the context, the sentence will be understood by the addressee(s). Similarly, Example (21b) is typically used in a restaurant to indicate who ordered what when the ordered food is served. To wit, all the copula shi does in these examples is express a relation between two items. What exactly the relation is is clear from the context.

In fact, as Example (22) illustrates, the verbs in the bare clauses discussed in the previous sections can also be substituted by shi without semantic consequences in the given contexts - note that the "substitution" by shi is only true descriptively. As will be shown below, the sentences in Example (22) are best analyzed as variants of the bare clauses we have been discussing all along.
a. 南希 是
胡桃夾子，
小十一
Nánxī shì
Hútáojiāzi,
xiăoShíyī
Nancy COP
'Nancy is The Nutcracker, El is Swan Lake.'
是 天鵝湖。
shì Tiān'éhú.
The.Nutcracker little.Eleven
COP Swan.Lake
b. 八點 是 胡桃夾子, 十點 是 天鵝湖。
Bādiăn shì Hútáojiāzi, shídiăn shì Tiān'éhú.
8.o'clock COP The.Nutcracker 10.o'clock COP Swan.Lake
'The Nutcracker is at eight o'clock, Swan Lake is at ten o'clock.'
c. 南希 是 左邊, 小十一 是 右邊。
Nánxī shì zuǒbiān, xiăoShíyī shì yòubiān.
Nancy COP left.side little.Eleven COP right.side
'Nancy is on the left side, El dance is the right side.'

In addition, shì in Example (22) can be omitted, giving rise to an immediate combination of two noun phrases (NPs), e.g., Example (23). Such cases have been analyzed as nominal predicate sentences (Chao 1968; Zhu 1982; Feng 1986; Tang 2003; Zhang 2010, among others) or as empty verb sentences (Tang 2001a).
a. 他
日本
女人。
Tā Rìběn nürén.
3SG.M Japan female
'He, a Japanese woman.'
b. 我雞肉, 他牛肉。
Wǒ jīròu, tā niúròu.
1SG chicken.meat $3 \mathrm{SG}$ beef
'I, chicken and he, beef.'

Shì omission can also be applied to the sentences in Example (22), resulting in those in Example (24).
a. 南希
胡桃夾子,
小十一
天鵝湖。
Nánxī Hútáojiāzi,
xiăoShíyī
Tiān'éhú.
Nancy The.Nutcracker little.Eleven
'Nancy, The Nutcracker, El, Swan Lake.'
Swan.Lake 
$\begin{array}{llll}\text { b. 八點 } & \text { 胡桃夾子, } & \text { 十點 } & \text { 天鵝湖。 } \\ \text { Bādiăn } & \text { Hútáojiāzi, } & \text { shídiăn } & \text { Tiān'éhú. } \\ \text { 8.o'clock } & \text { The.Nutcracker } & \text { 10.o'clock } & \text { Swan.Lake }\end{array}$

'Eight o'clock, The Nutcracker, ten o'clock, Swan Lake.'

c. 南希左邊, 小十一 右邊。

Nánxī zuǒbiān, xiăoShíyī yòubiān.

Nancy left.side little.Eleven right.side

'Nancy, on the left side, El, the right side.'

Interestingly, shi can also co-occur with bare predicates, as is illustrated in Example (25b), a variant of Example (25a) with copula shi.
a. 南希 跳
胡桃夾子,
小十一
跳 天鵝湖。
Nánxī tiào Hútáojiāzi,
xiăoShíyī tiào
Tiān'éhú.
Nancy dance The.Nutcracker little.Eleven dance Swan.Lake
lit. 'Nancy dance The Nutcracker, El dance Swan Lake.'
b. 南希 是 跳 胡桃夾子, 小十一 是 跳 天鵝湖。
Nánxī shì tiào Hútáojiāzi, xiăoShíȳi shì tiào Tiān'éhú.
Nancy COP dance The.Nutcracker little.Eleven COP dance Swan.Lake lit. 'Nancy is dance The Nutcracker, $\mathrm{El}$ is dance Swan Lake.'

This use of shi has been mentioned (though not discussed at any length) in many previous studies (Chao 1968; Zhu 1982; Lü 1999, among others). Example (26), for instance, is a sentence adapted from Zhu 1982: 105. Shi in such a case is optional, and when it is used, it is pronounced in a weaker way (with a neutral tone, see Zhu 1982: 105) than when it links two NPs. ${ }^{10}$

$$
\begin{aligned}
& \text { 他是去送人, 我是去接人。 } \\
& \text { Tā shì qù sòngrén, wǒ shì qù jiērén. } \\
& \text { 3SG COP go see.off.people 1SG COP go pick.up.people }
\end{aligned}
$$

Furthermore, the sentences in Examples (21), (23), and (26) have the temporally free interpretation with respect to the events denoted, just like the bare clauses under investigation. For instance, Example (26) remains true regardless of the temporal order between the seeing-off and picking-up events and the utterance time. Likewise, if Examples (21b) and (23b) are used to talk about ordering food, the real "ordering" event can be past, future, or present relative to the utterance time. As before, only a paired relation is expressed.

In sum, the above cases show that bare clauses under investigation establish a paired relation in the same way as the "special" type of copular

10 Although the copula shi in Mandarin is well-known for standardly taking nominal predicates, it is not absolutely impossible for it to take verbal predicates (see also Chao 1968; Zhu 1982, among others). 
sentences. In addition, bare verbs can be "substituted" by shì or co-occur with it. Crucially, both allow temporally free interpretation. Finally, whatever is relevant with respect to the distinction between Examples (21) and (23) in terms of the occurrence of shi is also relevant for the contrast between the sentences in Examples (22) and (24).

All the modified versions reviewed above taken together indicate that we have an inventory of four types of sentences that generally express comparable meanings, as presented in Examples (27a)-(27d).
a. 南希 跳 胡桃夾子, 小十一 Nánxī tiào Hútáojiāzi, xiăoShíyī
跳 天鵝湖。 $(=[25 \mathrm{a}])$
Nancy dance The.Nutcracker little.Eleven dance Swan.Lake lit. 'Nancy dance The Nutcracker, El dance Swan Lake.'
b. 南希 是 胡桃夾子, 小十一 是 天鵝湖。 $(=[22 \mathrm{a}])$
Nánxī shì Hútáojiāzi, xiăoShíȳi shì Tiān'éhú.
Nancy COP The.Nutcracker little.Eleven COP Swan.Lake

'Nancy is The Nutcracker, El is Swan Lake.'
c. 南希 胡桃夾子, 小十一 天鵝湖。 $(=[24 \mathrm{a}])$
Nánxī Hútáojiāzi, xiăoShíyī Tiān'éhú.
Nancy The.Nutcracker little.Eleven Swan.Lake

'Nancy, The Nutcracker, El, Swan Lake.'

d. 南希 是 跳 胡桃夾子, 小十一 是 跳 天鵝湖。 $(=[25 \mathrm{~b}])$ Nánxī shì tiào Hútáojiāzi, xiăoShíȳi shì tiào Tiān'éhú.

Nancy COP dance The.Nutcracker little.Eleven COP dance Swan.Lake lit. 'Nancy is dance The Nutcracker, El is dance Swan Lake.'

These examples differ along two lines: the presence or absence of the copula shi and the category of the predicate following the copula (DP or VP). Specifically, combinations of different values of the two factors result in four different situations, namely, an overt copula plus a DP predicate, e.g., Example (27b); an overt copula plus a VP predicate, e.g., Example (27d); no copula plus a DP predicate, e.g., Example (27c); and, lastly, no copula plus a VP predicate, e.g., Example (27a). From this perspective, the bare sentences that the current study focuses on instantiates one of the possibilities, namely, no copula and a VP predicate.

\subsection{The structure}

To reflect the above-mentioned parallel behavior between the bare clauses under investigation and copular structures, and especially to capture the paired relation that bare clauses express, this subsection proposes a predicative structure resembling copular structures for bare clauses when they have a temporally free interpretation. The subject NP is not the external argument of the predicate VP, but instead, it is related to the verb by a linking element, the copula. 
As the focus of this paper is not on the syntactic status of the Mandarin copula shi (addressing the question whether it is a $\mathrm{T}, v, \mathrm{~V}$, or any other possible head; see Arche et al. 2019 and Cheng 2021), I leave this question aside and present the copula as a relator in the clause and use the $\mathrm{R}$ (Relation head) as a cover name for the functional head that hosts it, in the spirit of Den Dikken (2006). The relator can be overtly realized as the copula shi, and cases without overt shi can be analyzed as R being phonetically null. ${ }^{11}$ Accordingly, the basic underlying structure corresponding to the four combinations is presented in Example (28), with each of the four alternative instantiations as given in Example (29).

(28)

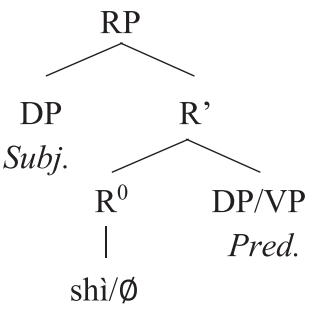

(29) The four alternative instantiations of Example (28)

a. Overt copula plus DP predicate

南希 是 胡桃夾子。
Nánxī shì Hútáojiāzi.
Nancy COP The.Nutcracker
'Nancy is The Nutcracker.'

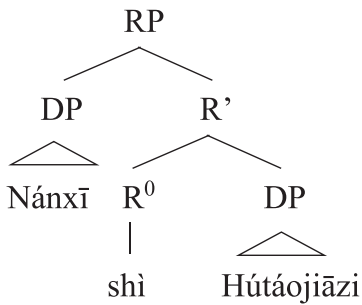

b. Overt copula plus VP predicate

$\begin{array}{llll}\text { 南希 } & \text { 是 } & \text { 跳 } & \text { 胡桃夾子。 } \\ \text { Nánxī shì } & \text { tiào } & \text { Hútáojiāzi. } \\ \text { Nancy } & \text { COP dance } & \text { The.Nutcracker } \\ \text { lit. 'Nancy is dance The Nutcracker.' }\end{array}$

11 The current study will not zoom in on the discussion about the type of copular sentences that these bare clauses belong to, be it predicational, specificational, or equative copular sentences. As these sentences have the interpretation of pair-lists, we can think of them either as topic-comment structures or as structures that express some kind of identity relation between the subject and the predicate. Examples such as Examples (31) and (33) provide a piece of empirical evidence that the word order of the two constituents flanking $\mathrm{R}$ is reversible. Additionally, there is no semantic change between the predicative and specificational reading when the word order is the opposite. 


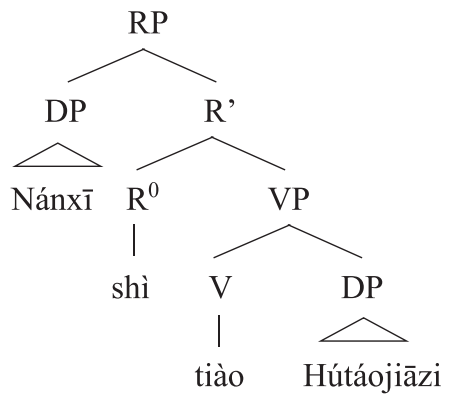

c. Covert copula plus DP predicate

南希胡桃夾子。

Nánxī Hútáojiāzi.

Nancy The.Nutcracker

'Nancy, The Nutcracker.'

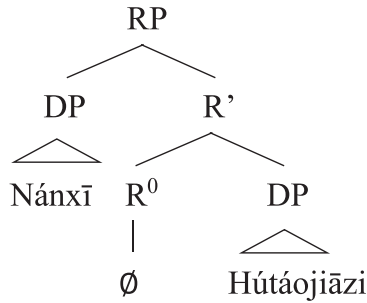

d. Covert copula plus VP predicate

南希跳胡桃夾子。

Nánxī tiào Hútáojiāzi.

Nancy dance The.Nutcracker

lit. 'Nancy dance The Nutcracker.'

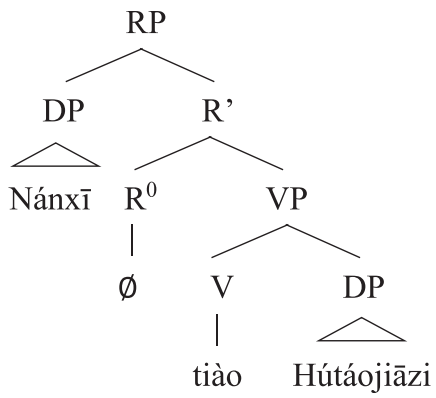

It is worth pointing out that bare clauses do not involve movement of the bare verb from V to R. That is, Example (30) does not present the correct derivation for bare clauses, cf. Example (29d). 
(30)

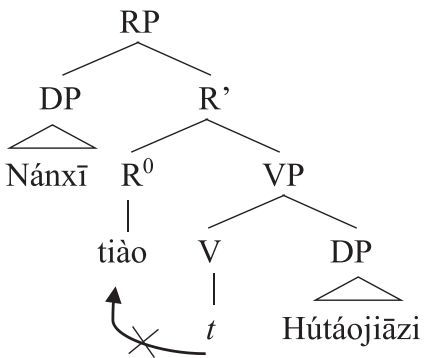

First, the structures proposed in Example (29) present a neat pattern resulting from the interaction between the (non)occurrence of the copula shi and the category of the predicate following it (DP or VP). From a theoretical perspective, there is no motivation for the verb to move. A piece of empirical evidence is the fact that the constituents flanking the copula shi can change qua word order regardless of whether the initial postcopular constituent is a DP or a VP, e.g., Sentence (31). In contrast, those flanking the bare verb cannot do so, as is testified by the ungrammaticality of Example (32).

a. 胡桃夾子 $\quad$ 是 南希。(cf. [29a])
Hútáojiāzi shì Nánxī.
The.Nutcracker COP Nancy
'The Nutcracker is Nancy.'
b. 跳 胡桃夾子 是 南希。(cf. [29b])
Tiào Hútáojiāzi shì Nánxī.
dance The.Nutcracker COP Nancy
lit. 'Dance The Nutcracker is Nancy.'

$\begin{array}{lll}\text { *胡桃夾子 } & \text { 跳 } & \text { 南希。(cf. [29d]) } \\ \text { *Hútáojiäzi } & \text { tiào } & \text { Nánxī. } \\ \text { The.Nutcracker } & \text { dance } & \text { Nancy }\end{array}$

The fact that in Example (31b), the whole VP is moved to the front of the sentence can also be seen as confirmation for the structure in Example (29), with the whole VP constituting one constituent in the complement position of R.

Another interesting fact about the sentences in Examples (31b/33) is that the copula shi is obligatory. It has been attested in standard copular sentences in Mandarin (e.g., Tang 2001a; Cheng 2021) and cross-linguistically (e.g., Heycock 1995; Moro 1997; Den Dikken 2006) that the overt occurrence of the copula is obligatory in specificational predication structures. For instance, as shown in Examples (34) and (35), the copula is optional in one order but obligatory in the reversed order.

$\begin{array}{llrl}\text { 跳 } & \text { 胡桃夾子 } & *(\text { 是) } & \text { 南希。 } \\ \text { Tiào } & \text { Hútáojiāzi } & *(\text { shì }) & \text { Nánxī. } \\ \text { dance } & \text { The.Nutcracker } & \text { COP } & \text { Nancy } \\ \text { lit. 'Dance The Nutcracker is Nancy.' }\end{array}$




$\begin{array}{lll}\text { a. 今天 } & \text { (是) } & \text { 星期日。 } \\ \text { Jīntiān } \quad \text { (shì) } & \text { Xīngqīrì. } \\ \text { today COP } & \text { Sunday } \\ \text { 'Today is Sunday.' } & \\ \text { b. 星期日 *(是) } & \text { 今天。 } \\ \text { Xīngqīrì } & * \text { (shì) } & \text { jīntiān. } \\ \text { Sunday COP } & \text { today } \\ \text { 'Sunday is today.' } & \end{array}$

(35) a. I consider [[John] (to be) [the culprit]].

b. * I consider [[the culprit] * (to be) [John]]. (adapted from Heycock 1995: 227)

\subsection{Accounting for the temporal interpretation}

How can the structure in Example (28) account for the free temporal interpretation of bare clauses given the right contexts? I attribute the free temporal interpretation to the absence of TP and AspP below $\mathrm{R}$ in the structure of bare clauses. In other words, the temporal interpretation in our sentences is un- or underspecified.

First, the complement of $\mathrm{R}$ is either a VP or a DP, without an AspP and TP projected as part of this constituent. This means that even for the VP, there is no projection for the expression of aspect or tense that determines the positioning of the event relative to the utterance time. All we have is the lexical VP. Empirically, no aspect markers or temporal adverbials anchoring to the utterance time can be attached to verbs in the bare clauses. In other words, it is not the case that these bare clauses receive a special type of interpretation as Sun (2015) proposes, i.e., "temporally free" interpretation in specific contexts. Rather, the temporal specification is absent. Bare clauses are indeed tempus-less.

The lack of temporal specification is also in line with the observation that the temporal interpretation of bare sentences is a function of the context alone. With the absence of aspectual markers or/and temporal adverbials anchoring to the utterance time, bare clauses provide no clue about the temporal relation between the time of the event and the utterance time. In many contexts, the temporal order is irrelevant or even unknown to the speakers/addressees, in other words, the only thing bare clauses establish formally is a paired relation.

However, although there may be no TP or AspP in the complement of R, how about the functional superstructure of $\mathrm{R}$ itself? Is it not dominated by the superstructure that we find in other sentences and that may involve a TP and AspP? As an answer to this question, I would like to point out that the bare sentences discussed in this paper behave in exactly that same way as regular copular sentences in Mandarin. As a result, we can stay agnostic about the question of what kind of superstructure they are embedded in. Consider the sentences in Example (36). 


$$
\begin{aligned}
& \text { 張三 是 老師。 } \\
& \text { Zhāngsān shì lăoshī. } \\
& \text { Zhangsan COP teacher } \\
& \text { 'Zhangsan is/was a teacher.' }
\end{aligned}
$$

The predominant reading for the predicational copular sentence in Example (36) is that Zhangsan is a teacher at the utterance time. However, Example (36) can also be used when Zhangsan has already passed away, in which context Zhangsan being a teacher is a conceptually past state.

Furthermore, assuming Zhangsan's father is still alive but his grandfather is not, copular sentences containing a coordination of two noun phrases referring to them as subjects (cf. Example [37a]) are grammatical, as are elliptical sentences such as Example (38a). However, if the copular sentences are changed into sentences with an activity verb, as in Examples (37b) and (38b), they are no longer felicitous in the same contexts.
a. 張三
的
爸爸 和
爺爺都是
物理
老師。

\begin{tabular}{|c|c|c|c|c|c|}
\hline $\begin{array}{l}\text { \#張三 } \\
\text { \#Zhāngsān } \\
\text { Zhangsan }\end{array}$ & $\begin{array}{l}\text { 的 } \\
\text { de } \\
\text { SUB }\end{array}$ & $\begin{array}{l}\text { 爸爸 } \\
\text { bàba } \\
\text { dad }\end{array}$ & $\begin{array}{l}\text { 和 } \\
\text { hé } \\
\text { and }\end{array}$ & $\begin{array}{l}\text { 爺爺 } \\
\text { yéye } \\
\text { grandpa }\end{array}$ & $\begin{array}{l}\text { 都 } \\
\text { dōu } \\
\text { all }\end{array}$ \\
\hline
\end{tabular} Zhāngsān de bàba hé yéye dōu shì wùlī lăoshī. Zhangsan SUB dad and grandpa all COP physics teacher 'Both Zhangsan's dad and grandpa are physics teachers.'

'Both Zhangsan's dad and grandpa teach physics.'
a. 張三
的爸爸是
物理 老師, 張三
的 爺爺
也是。 Zhāngsān de bàba shì wùlì lăoshī, Zhāngsān de yéye yě shì. Zhangsan SUB dad COP physics teacher Zhangsan SUB grandpa too SHI 'Zhangsan's dad is a physics teacher, his grandpa too.'
b. 䉼張三
的爸爸教
物理, 張三
的爺爺
也 是。
\#Zhāngsān de bàba jiāo
wùlǐ,
Zhāngsān de yéye
yě shì.
Zhangsan SUB dad teach physics Zhangsan SUB grandpa too SHI
'Zhangsan's dad teaches physics, his grandpa too.'

These facts and the contrast between copular and verbal predication indicate that (at least a group of) copular predication differs from verbal predication in that it is not associated with a specific temporal reference in the way that verbal predication is. This study will not enter into the discussion about the question whether copular sentences involve a TP or not; all that is relevant here is that our bare clauses behave in the same way as copular sentences with respect to their temporal interpretation (however this behavior is explained).

In short, the proposed analysis of temporally free bare clauses is that they establish pairings between a nominal entity and a predicate. The predicate is structurally bare in that it is not dominated by the functional structure on top of the VP, such as a TP or AspP projection. With respect to their temporal interpretation, 
sentences thus formed behave like (other) copular sentences in Mandarin. Section 4 will show that bare clauses under investigation have other properties in common with copular sentences as well.

\section{Further support for the proposed analysis}

This section presents further support for the analysis of bare clauses proposed in Example (28). The first piece of evidence comes from the observation that bare clauses pattern with copular sentences with respect to the availability of gapping. The other concerns negation: when negating bare clauses, shi is obligatorily used.

\subsection{Gapping}

It has been claimed that Mandarin lacks canonical gapping (Paul 1999; Tang 2001b; Wei 2011). For instance, Example (39a), a standard aspectually marked episodic sentence, cannot partake in the (under some analyses, elliptical) structure referred to as gapping. Example (39b), on the contrary, seems to be well formed.

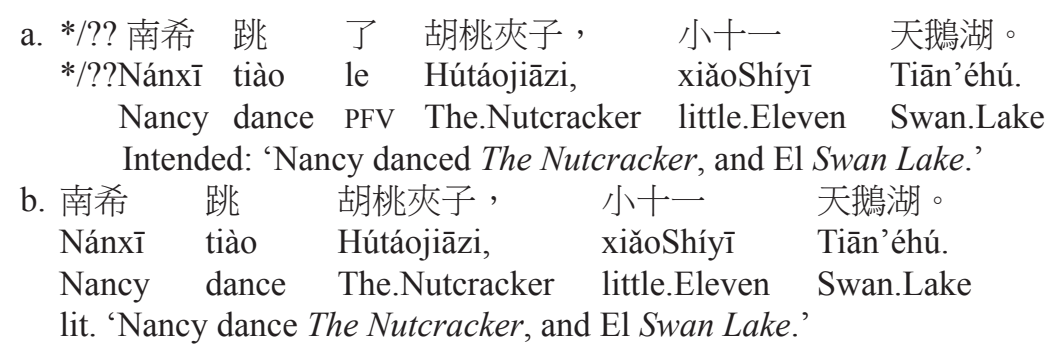

What has not been noticed is that Mandarin copular sentences do allow for gapping. Even if Example (40) is not perfectly acceptable, it is in any case much better than Example (39a).

$$
\begin{aligned}
& \text { ? 南希 是 芭蕾舞 演員, 小十一 民族舞 演員。 } \\
& \text { ? Nánxī shì bāléiwǔ yănyuán, xiăoShíȳi mínzúwǔ yănyuán. } \\
& \text { Nancy COP ballet actress little.Eleven folk.dance actress } \\
& \text { 'Nancy is a ballet dancer, El folk dancer.' }
\end{aligned}
$$

The same pattern can be observed when the verb in a bare clause, Example (39b), is substituted by the copula shi, e.g., Sentence (41), and also when the copula shi co-occurs with VP predicates, e.g., Sentence (42).

$\begin{array}{llll}\text { 南希 是 } & \text { 芭蕾舞, 小十一 } & \text { 艮族舞。(cf. [27b]) } \\ \text { Nánxī shì băéiwú, } & \text { xiăoShíyī } & \text { mínzúwŭ. } \\ \text { Nancy COP ballet } & \text { little.Eleven } & \text { folk.dance } \\ \text { 'Nancy is ballet, El folk dance.' } & \end{array}$
a. 南希 是 跳 胡桃夾子, 小十一 天鵝湖。(cf. [27d])
Nánxī shì tiào Hútáojiāzi, xiăoShíyī Tiān'éhú.
Nancy COP dance The.Nutcracker little.Eleven Swan.Lake lit. 'Nancy dance The Nutcracker, El Swan Lake.' 

b. 他是去送人, 我接人。(cf. [26])
Tā shì qù sòngrén, wǒ jiērén.
3SG COP go see.off.people 1SG pick.up.people

'What he did/is going to do is seeing off people; whereas what I did/am going to do is picking up people.'

This contrast shows that bare clauses pattern with copular sentences but differ from episodic sentences when it comes to gapping, supporting the claim that bare clauses are copular structures.

\subsection{Negation}

Unlike episodic sentences, bare clauses cannot be directly negated by the negators bù or méi. Example (43a) is a perfective sentence in the negative form, and the verb is directly negated by méi. Similarly, Example (43b), when uttered in isolation, has a future reading or generic reading and its verb is directly negated by negator bù.

a. 南希 沒 跳 胡桃夾子。
Nánxī méi tiào Hútáojiāzi.
Nancy NEG dance The.Nutcracker
'Nancy didn't dance The Nutcracker.'
b. 南希 不 跳 胡桃夾子。
Nánxī bù tiào Hútáojiāzi.
Nancy NEG dance The.Nutcracker
'Nancy is not going to dance The Nutcracker.'
or 'Nancy does not dance The Nutcracker.'

Sentences in Example (44) show that bare clauses cannot be negated by either bù or méi while maintaining the free temporal interpretation. Instead, a complex negation form bù-shì must be used either at the sentence-initial or in the postsubject position. ${ }^{12}$
a. */??南希 不 跳 胡桃夾子, 小十一 不 跳 天鵝湖。 */??Nánxī bù tiào Hútáojiāzi, xiăoShíȳi bù tiào Tiān'éhú.
Nancy NEG dance The.Nutcracker little.Eleven NEG dance Swan.Lake Intended: lit. 'Nancy not dance The Nutcracker, El not dance Swan Lake.'
b. *南希 沒 跳 胡桃夾子, 小十一 沒 跳 天鵝湖。 *Nánxī méi tiào Hútáojiāzi, xiăoShíȳi méi tiào Tiān'éhú. Nancy NEG dance The.Nutcracker little.Eleven NEG dance Swan.Lake Intended: lit. 'Nancy not dance The Nutcracker, El not dance Swan Lake.'

12 Some of my informants would accept Example (44a) as a proper negation form of the bare clause. Even for this set of speakers, there is a difference between Examples (44a) and (45a): Example (45a) is regarded as much better than Example (44a). 

a. 南希不 是 跳胡桃夾子, 小十一 不 是 Nánxī bù shì tiào Hútáojiāzi, xiăoShíȳi bù shì Nancy NEG COP dance The.Nutcracker little.Eleven NEG COP 跳天鵝湖。
tiào Tiān'éhú.
dance Swan.Lake
lit. 'Nancy is not dance The Nutcracker, El is not dance Swan Lake.'
b. 不 是 [南希 跳胡桃夾子, 小十一 跳 天鵝湖]。 Bù shì [Nánxī tiào Hútáojiāzi, xiăoShíȳ̄ tiào Tiān'éhú]. NEG COP Nancy dance The.Nutcracker little.Eleven dance Swan.Lake lit. 'It is not the case that Nancy dance The Nutcracker, El dance Swan Lake.'

While the details are unclear, this pattern can receive an analysis in terms of Example (28). Possibly, instead of directly negating the bare verb, bù negates the relator element $\mathrm{R}$, which, as we have specified above, can in principle be overt or covert. However, since bù cannot stand alone, in negative contexts, the relator cannot be covertly realized and must be overtly realized as shi. This explains why the only form of negation that is acceptable in bare clauses is bì-shi.

\section{Conclusion}

The current study proposes that the temporal interpretation of Mandarin bare clauses is underspecified in contexts that focus on a paired relation describing a planned or scheduled event, the interpretation of the temporal relation with the utterance time being a function of the context. A bare clause establishes a paired relation between a subject and a VP, with no temporal information encoded. In structural terms, it is proposed that the relation between the subject and the VP is mediated by a copula, which may or may not be overt. The combination of the subject and the predicate does not include any TP or AspP: it is truly bare. Furthermore, it is pointed out that bare clauses behave in exactly the same way when it comes to temporal interpretation as regular copular sentences in Mandarin.

\section{Acknowledgments}

I am indebted to Rint Sybesma and Anikó Lipták for extensive discussion on the current work. I am also grateful to Lisa Cheng, Chen Ran, Zhaole Yang, Astrid van Alem, two anonymous reviewers, and the audience of the "CHILL" (Chinese Linguistics in Leiden) workshop on Chinese linguistics held at Leiden University for valuable comments on earlier versions of this paper. I owe deeply to all the helpful informants on the data. All the remaining errors and shortcomings are mine.

\section{References}

Akmajian, Adrian. 1984. Sentence types and the form-function fit. Natural Language and Linguistic Theory 2(1). 1-23.

Arche, María J., Antonio Fábregas \& Rafael Marín (eds.). 2019. The grammar of copulas across languages. New York: Oxford University Press. 
Chao, Yuen-Ren. 1968. A grammar of spoken Chinese. Berkeley: University of California Press.

Cheng, Hang. 2021. All structures great and small: On copular sentences with shì in Mandarin. Leiden: Leiden University dissertation.

Copley, Bridget. 2008. The plan's the thing: Deconstructing futurate meanings. Linguistic Inquiry 39(2). 261-274.

Den Dikken, Marcel. 2006. Relators and linkers: The syntax of predication, predicate inversion, and copulas. Cambridge, MA: MIT Press.

Feng, Ping. 1986. Tan mingci chongdang weiyu [On nouns functioning as predicates]. Hanyu Xuexi [Chinese language learning] 3. 21-22.

Heycock, Caroline. 1995. The internal structure of small clauses: New evidence from inversion. In Jill N. Beckman (ed.), Proceedings of NELS 25, 223-238. Amherst: GLSA University of Massachusetts.

Klein, Wolfgang, Ping Li \& Hemriette Hendriks. 2000. Aspect and assertion in Mandarin Chinese. Natural Language and Linguistic Theory 18(4). 723-770.

Lambrecht, Knud. 1990. "What, me worry?” - 'Mad Magazine sentences' revisited. In Kira Hall (ed.), Proceedings of the Sixteenth Annual Meeting of the Berkeley Linguistics Society 16(1), 215-228. Berkeley: Berkeley Linguistics Society.

Lin, Jo-Wang. 2002. Selectional restrictions of tenses and temporal reference of Chinese bare sentences. Lingua 113(3). 271-302.

Lin, Jo-Wang. 2006. Time in a language without tense: The case of Chinese. Journal of Semantics 23(1). 1-53.

Lin, Jo-Wang. 2010. A tenseless analysis of Mandarin Chinese revisited: A response to Sybesma 2007. Linguistic Inquiry 41(2). 305-329.

Lü, Shuxiang. 1999. Xiandai Hanyu babai ci (zengding ben) [Eight hundred words in contemporary Chinese (enlarged edition)]. Beijing: Shangwu Yinshuguan [The commercial press].

Moro, Andrea. 1997. The raising of predicates: Predicative noun phrases and the theory of clause structure. Cambridge \& New York: Cambridge University Press.

Paul, Waltraud. 1999. Verb gapping in Chinese: A case of verb raising. Lingua 107(3-4). 207-226.

Smith, Carlota \& Mary S. Erbaugh. 2005. Temporal interpretation in Mandarin Chinese. Linguistics 43(4). 713-756.

Sun, Hongyuan. 2014. Temporal construals of bare predicates in Mandarin Chinese. Leiden: Leiden University dissertation.

Sun, Hongyuan. 2015. Evidence against a scope analysis of temporally free readings of relative clauses in Mandarin. Cahiers Chronos 27. 59-77.

Tang, Sze-Wing. 2001a. Nominal predication and focus anchoring. In Gerhard Jäger, Anatoli Strigin, Chris Wilder \& Niina Ning Zhang (eds.), ZAS papers in linguistics 22, 159-172. Berlin: ZAS.

Tang, Sze-Wing. 2001b. The (non-)existence of gapping in Chinese and its implications for the theory of gapping. Journal of East Asian Linguistics 10(3). 201-224.

Tang, Sze-Wing. 2003. Verbless adverbial clauses and economy. In Jie Xu, Donghong Ji \& Kim Teng Lua (eds.), Chinese syntax and semantics, 157-176. Singapore: Prentice Hall. 
Wei, Ting-Chi. 2011. Subordinate gaps in Mandarin Chinese. Taiwan Journal of Linguistics 9(1). 51-87.

Yong, Shin. 1997. The grammatical functions of verb complements in Mandarin Chinese. Linguistics 35(1). 1-24.

Zhang, Heyou \& Sze-Wing Tang. 2010. Yu kongyulei xiangguan de teyixing “shi” ziju de jufa, yuyi [On the syntax and semantics of the idiosyncratic copular sentences and empty categories]. Dangdai Yuyanxue [Contemporary linguistics] 1. 14-23.

Zhang, Qingwen. 2010. On the syntax of non-verbal predication in Mandarin Chinese. Hong Kong: Hong Kong Polytechnic University dissertation.

Zhu, Dexi. 1982. Yufa jiangyi [Lecture notes on grammar]. Bejing: Shangwu Yinshuguan [The commercial press].

$\begin{array}{ll}\text { Mailing address: } & \begin{array}{l}\text { Hang Cheng } \\ \text { Leiden University Centre for Linguistics, Reuvensplaats 2/0.74, 2311 } \\ \text { BE, Leiden, The Netherlands }\end{array} \\ \text { Email: } & \begin{array}{l}\text { h.cheng@ @um.leidenuniv.nl } \\ \text { Received: }\end{array} \\ \text { Accepted: } & \text { January } 15,2020\end{array}$




\title{
漢語光杆動詞句與時態非特定性
}

\author{
程航 \\ 萊頓大學
}

\section{提要}

本文討論了事前計劃語境下漢語普通話光杆動詞句的特殊時間詮釋。該語境下, 漢 語普通話光杆動詞句的時態表達具有非特定性, 依具體說話時間而定。基於此類光 杆動詞句的特殊句法表現及對語境的選擇、“是” 字的隱現特點及與系詞句在句法 變換和時間表達上的平行性, 本文論證該類光杆動詞句具有系詞句結構。其時間表 達上的非特定性則源於句法結構中與時間表達相關的投射的缺失。

\section{關鍵詞}

光杆動詞句, 計劃語境, 時態非特定性, 系詞句 